\begin{tabular}{r|l|l|l}
$\begin{array}{c}\text { Case Reports in } \\
\text { Gastroenterology }\end{array}$ & $\begin{array}{l}\text { Case Rep Gastroenterol 2010;4:374-380 } \\
\text { DOl: 10.1159/000320674 }\end{array}$ & $\begin{array}{l}\text { Published online: } \\
\text { September 18, 2010 }\end{array}$ & $\begin{array}{l}\text { O 2010 S. Karger AG, Basel } \\
\text { ISSN 1662-0631 } \\
\text { www.karger.com/crg }\end{array}$ \\
\hline
\end{tabular}

\title{
Spindle Cell Carcinoma of the Common Bile Duct: Case Report with Immunohistochemical Analysis
}

\author{
Tadashi Terada \\ Department of Pathology, Shizuoka City Shimizu Hospital, Shizuoka, Japan
}

\section{Key Words}

Spindle cell carcinoma $\cdot$ Common bile duct $\cdot$ Immunohistochemistry

\begin{abstract}
The author reports a very rare case of spindle cell carcinoma of the common bile duct with an emphasis on immunohistochemical features. A 65-year-old man was admitted to our hospital because of jaundice. Imaging modalities revealed a tumor of the common bile duct, and bile cytology demonstrated malignant cells. A pancreatico-duodenectomy was performed. Grossly, an elevated tumor $(15 \times 10 \times 3 \mathrm{~mm})$ was present in the middle portion of the common bile duct. Microscopically, the tumor consisted of well-differentiated adenocarcinoma ( $20 \%$ in area) and spindle cell carcinoma ( $80 \%$ in area). There were gradual transitions between the two. The tumor cells invaded into the serosa. Immunohistochemically, the spindle cell carcinoma element was positive for four types of pancytokeratins, cytokeratin 7 (CK7), CK8, CK18, CK19, CK20, epithelial membrane antigen, vimentin, p53 protein, Ki-67 (labeling = $52 \%$ ), and CEA. It was negative for high-molecular-weight CK, CK5/6, CK14, p63, neuron-specific enolase chromogranin, synaptophysin, CD56, CA19-9, CD34, desmin, S100 protein, myoglobin, a-smooth muscle antigen, CD34, CD68 and KIT. The adenocarcinoma element showed similar immunoreactivity except for negative vimentin, and positive CA19-9. The present case is the first report of spindle cell carcinoma of the common bile duct demonstrating an extensive immunohistochemistry. The spindle cell carcinoma in the present case may be derived from sarcomatous transformation of the adenocarcinoma element. CK20 newly emerges in the development of spindle cell carcinoma of the common bile duct.
\end{abstract}

\section{Introduction}

Sarcomatoid carcinoma of the extra- and intrahepatic bile ducts is very rare; only a few case reports and case studies of small series have been reported [1-9]. In particular, 


\begin{tabular}{r|l|l|l}
$\begin{array}{r}\text { Case Reports in } \\
\text { Gastruanteriology }\end{array}$ & $\begin{array}{l}\text { Case Rep Gastroenterol 2010;4:374-380 } \\
\text { DOI: 10.1159/000320674 }\end{array}$ & $\begin{array}{l}\text { Published online: } \\
\text { September 18, 2010 }\end{array}$ & $\begin{array}{l}\text { O 2010 S. Karger AG, Basel } \\
\text { ISSN 1662-0631 } \\
\text { www.karger.com/crg }\end{array}$ \\
\hline
\end{tabular}

sarcomatoid carcinoma of the common bile duct is extremely rare [6-9]. Spindle cell carcinoma, a variant of sarcomatoid carcinoma, is also extremely rare in the common bile duct; only two case reports have been published in the English language literature $[8,9]$. There have been no reports examining extensive immunohistochemical features in sarcomatoid carcinoma of the biliary tree. The author herein presents a case of spindle cell carcinoma of the common bile duct with an emphasis on immunohistochemical features.

\section{Case Report}

A 65-year-old man was admitted to our hospital because of jaundice. Imaging modalities including ERCP, CT, and MRI revealed a tumor of the common bile duct, and bile cytology identified malignant cells. A pancreatico-duodenectomy was performed. Grossly, an elevated tumor $(15 \times 10 \times 3 \mathrm{~mm})$ was present in the middle portion of the common bile duct (fig. 1). Microscopically, the tumor consisted of well-differentiated adenocarcinoma (20\% in area) and spindle cell carcinoma ( $80 \%$ in area) (fig. 2 ). There were gradual transitions between the two. The tumor cells invaded into the serosa.

An immunohistochemical study was performed, using the Dako Envision method (Dako Corp., Glostrup, Denmark), as previously described [10-14]. The antigens examined and their results are shown in table 1. Immunohistochemically, the spindle cell carcinoma element was positive for four types of pancytokeratins, cytokeratin 7 (CK7) (fig. 3a), CK8, CK18 (fig. 3b), CK19, CK20, epithelial membrane antigen, vimentin (fig. 3c), p53 protein (fig. 3d), Ki-67 (labeling $=52 \%$ ), and CEA (fig. 3e). It was negative for high-molecular-weight CK, CK5/6, CK14, p63, neuron-specific enolase chromogranin, synaptophysin, CD56, CA19-9, CD34, desmin, S100 protein, myoglobin, $\alpha$-smooth muscle antigen, CD34, CD68 and KIT. The adenocarcinoma element showed similar immunoreactivity, except for negative vimentin and positive CA19-9 (table 1).

\section{Discussion}

Only two cases of spindle cell carcinoma of the common bile duct have been reported in the English language literature, to the best of the author's knowledge $[8,9]$. Oikawa et al. [8] reported a case of sarcomatous carcinoma of the common bile duct composed of spindle cells, giant cells, and adenocarcinoma cells. Their case was immunohistochemically positive for pancytokeratins, epithelial membrane antigen and vimentin. The diagnosis was spindle cell and giant cell undifferentiated carcinoma [8]. Nakanishi et al. [9] reported spindle cell carcinoma of the common bile duct at the hepatic hilus. Their case was composed of spindle cells and adenocarcinoma cells, and immunohistochemically positive for two kinds of pancytokeratin [9].

The present tumor was composed of a spindle cell carcinoma element $(80 \%$ in area) and a well-differentiated adenocarcinoma element ( $20 \%$ in area). Immunohistochemically, the tumor cells were positive for a wide range of CK, CEA and vimentin. They were also positive for $\mathrm{p} 53$ protein and Ki-67 antigen with high labeling indices. In contrast, they were negative for other mesenchymal markers and neuroendocrine markers. Therefore, the present tumor of the common bile duct is not a sarcoma but a carcinoma. Thus, spindle cell carcinoma was the correct diagnosis in the present study.

Sarcomatous transformation of carcinoma can occur in any carcinoma, though the frequency is very rare. In the present case also, the carcinoma was composed of spindle cell carcinoma and adenocarcinoma. There were gradual transitions between the two. 


\begin{tabular}{r|l|l|l}
$\begin{array}{r}\text { Case Reports in } \\
\text { Gastruenterology }\end{array}$ & $\begin{array}{l}\text { Case Rep Gastroenterol 2010;4:374-380 } \\
\text { DOI: 10.1159/000320674 }\end{array}$ & $\begin{array}{l}\text { Published online: } \\
\text { September 18, 2010 }\end{array}$ & $\begin{array}{l}\text { O 2010 S. Karger AG, Basel } \\
\text { ISSN 1662-0631 } \\
\text { www.karger.com/crg }\end{array}$ \\
\hline
\end{tabular}

These findings strongly suggest that the spindle cell carcinoma element is derived from sarcomatous transformation of the adenocarcinoma element. The immunohistochemical data support this hypothesis in the present case.

There have been few studies of immunohistochemistry in spindle cell carcinoma of the common bile duct $[8,9]$, and extensive immunohistochemical studies of sarcomatoid carcinoma of the biliary tree have been performed. CK profiling has not been performed in sarcomatoid carcinoma of the bile ducts. It is well known that bile duct epithelium shows CK7, CK8, CK18 and CK19. In the present study, these CKs and CK20 were positive, indicating that CK20 emerged during the carcinogenesis of the present tumor. Positive expression of vimentin indicates a sarcomatous nature of the present carcinoma. Positive expression of CEA suggests an adenocarcinomatous nature of the present spindle cell carcinoma.

Mesenchymal markers including S100 protein, $\alpha$-smooth muscle actin, CD34, myoglobin and desmin were absent in the present tumor, indicating that it was not a sarcoma but a carcinoma and that these antigens did not emerge during the spindle cell transformation of the adenocarcinoma of the present case. The present case was negative for neuroendocrine markers, suggesting that these antigens were absent from spindle cell carcinoma of the biliary tree. The present study also showed p53 protein and Ki-67 antigen. High Ki-67 labeling predict poor prognosis. In the present case, $\mathrm{Ki}-67$ labeling of both elements was very high, suggesting a poor prognosis. The present tumor was free of neuroendocrine markers (chromogranin, synaptophysin, neuron-specific enolase, and CD56). The present findings indicate that the present tumor was not a neuroendocrine tumor. The present case was negative for CD34, CD68 and KIT, suggesting that the present tumor was not a KIT-positive tumors such as extragastrointestinal stromal tumor or other carcinomas and sarcomas.

In summary, the present case is the first report of spindle cell carcinoma of the common bile duct demonstrating an extensive immunohistochemistry. The spindle cell carcinoma in the present case may be derived from sarcomatous transformation of an adenocarcinoma element. 


\begin{tabular}{r|l|l|l} 
Case Reports in & $\begin{array}{l}\text { Case Rep Gastroenterol 2010;4:374-380 } \\
\text { DOl: 10.1159/000320674 }\end{array}$ & $\begin{array}{l}\text { Published online: } \\
\text { September 18, 2010 }\end{array}$ & $\begin{array}{l}\odot \text { ISSN 1662-0631 } \\
\text { www.karger.com/crg }\end{array}$ \\
\hline
\end{tabular}

Table 1. Immunohistochemical reagents and results

\begin{tabular}{|c|c|c|c|c|}
\hline \multirow[t]{2}{*}{ Antigens } & \multirow{2}{*}{$\begin{array}{l}\text { Antibodies } \\
\text { (clone) }\end{array}$} & \multirow[t]{2}{*}{ Sources } & \multicolumn{2}{|l|}{ Results } \\
\hline & & & $\begin{array}{l}\text { spindle cell } \\
\text { carcinoma }\end{array}$ & $\begin{array}{l}\text { adeno- } \\
\text { carcinoma }\end{array}$ \\
\hline Pancytokeratin & $\mathrm{AE} 1 / 3$ & Dako Corp., Glostrup, Denmark & +++ & +++ \\
\hline Pancytokeratin & polyclonal wide & Dako & ++ & +++ \\
\hline Pancytokeratin & KL-1 & Immunotech, Marseille, France & +++ & +++ \\
\hline Pancytokeratin & CAM5.2 & Becton Dickinson Co., CA, USA & ++ & +++ \\
\hline HMWCK & $34 \beta \mathrm{E} 12$ & Dako & - & - \\
\hline CK5/6 & D5/16 & Dako & - & - \\
\hline CK7 & N1626 & Dako & +++ & +++ \\
\hline CK8 & $35 \beta \mathrm{H} 11$ & Dako & ++ & ++ \\
\hline CK14 & LL002 & Novocastra, Newcastle upon Tyne, UK & - & - \\
\hline CK18 & DC10 & Dako & +++ & +++ \\
\hline CK19 & RCK 108 & Progen, Heidelberg, Germany & ++ & ++ \\
\hline CK20 & K20.8 & Dako & + & ++ \\
\hline EMA & E29 & Dako & + & + \\
\hline Vimentin & Vim 3B4 & Dako & ++ & - \\
\hline CEA & polyclonal & Dako & + & ++ \\
\hline Desmin & D33 & Dako & - & - \\
\hline S100 protein & polyclonal & Dako & - & - \\
\hline Myoglobin & polyclonal & Dako & - & - \\
\hline ASMA & $1 \mathrm{~A} 4$ & Dako & - & - \\
\hline CD34 & NU-4A1 & Nichirei, Tokyo, Japan & - & - \\
\hline p53 protein & DO-7 & Dako & +++ & +++ \\
\hline p63 & polyclonal & Dako & - & - \\
\hline Ki-67 & MIB-I & Dako & $52 \%$ & $46 \%$ \\
\hline CA19-9 & NA19-9 & TFB Lab, Tokyo, Japan & - & + \\
\hline Chromogranin & DAK-A3 & Dako & - & - \\
\hline Synaptophysin & polyconal & Dako & - & - \\
\hline NSE & BBS/NC/VI-H14 & Dako & - & - \\
\hline CD56 & UJ13A & Dako & - & - \\
\hline CD68 & KP-1 & Dako & - & - \\
\hline KIT & polyclonal & Dako & - & - \\
\hline
\end{tabular}

$+++=67-100 \%$ positive; $++=33-67 \%$ positive $;+=1-33 \%$ positive $;-=$ negative

HMWCK = High-molecular-weight cytokeratin; CK = cytokeratin; EMA = epithelial membrane antigen; CA19-9 = carcinoma antigen 19-9; CEA = carcinoembryonic antigen; ASMA $=\alpha$-smooth muscle antigen; NSE = neuron-specific enolase. 


\begin{tabular}{r|l|l|l}
$\begin{array}{r}\text { Case Reports in } \\
\text { Gastruenterology }\end{array}$ & $\begin{array}{l}\text { Case Rep Gastroenterol 2010;4:374-380 } \\
\text { DOI: 10.1159/000320674 }\end{array}$ & $\begin{array}{l}\text { Published online: } \\
\text { September 18, 2010 }\end{array}$ & $\begin{array}{l}\text { O 2010 S. Karger AG, Basel } \\
\text { ISSN 1662-0631 } \\
\text { www.karger.com/crg }\end{array}$ \\
\hline
\end{tabular}

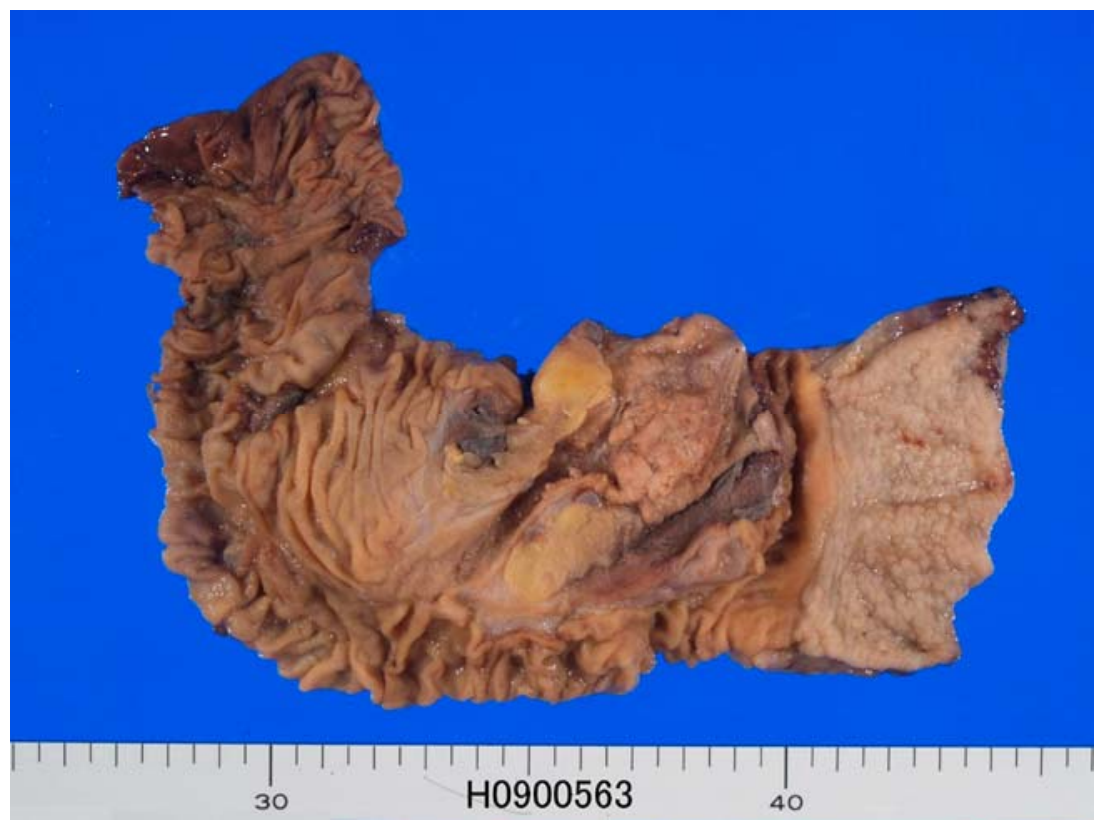

Fig. 1. Gross features of the common bile duct tumor. An elevated tumor is seen (central part).
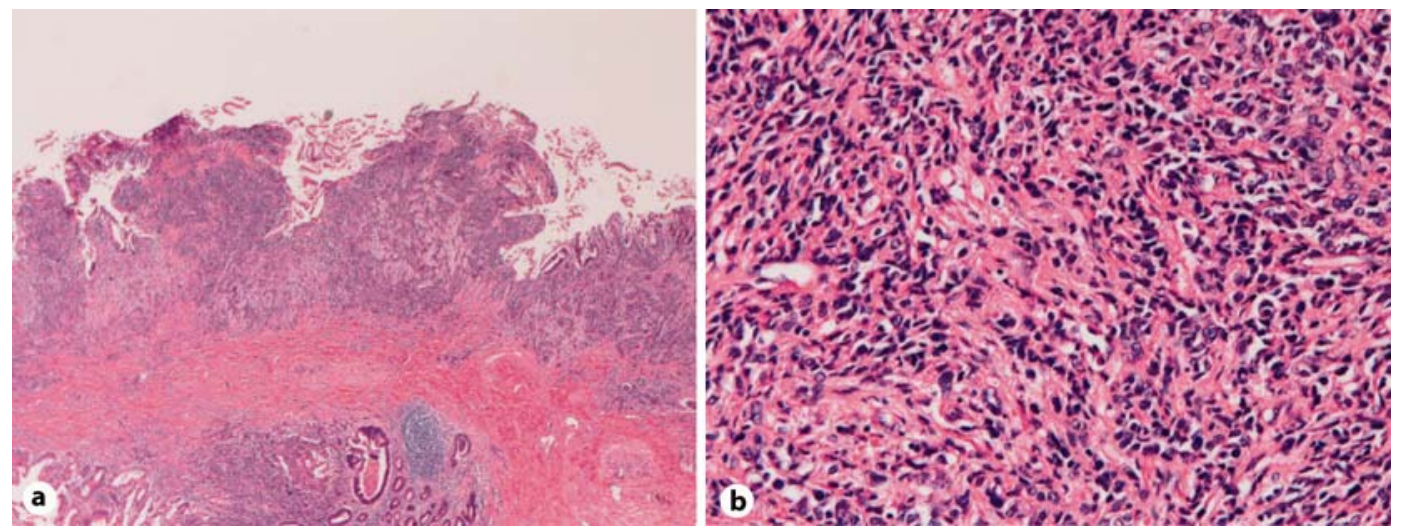

Fig. 2. a Microscopic features. The spindle cell carcinoma element (upper) and the adenocarcinoma element (lower) are seen. There is a gradual transition between the two. HE, $\times 20$. $\mathbf{b}$ High power view of the spindle cell carcinoma element. Malignant features are apparent. There are many mitotic figures. $\mathrm{HE}, \times 100$. 


\begin{tabular}{r|l|l|l}
$\begin{array}{r}\text { Case Reports in } \\
\text { Gastroanterology }\end{array}$ & $\begin{array}{l}\text { Case Rep Gastroenterol 2010;4:374-380 } \\
\text { DOl: 10.1159/000320674 }\end{array}$ & $\begin{array}{l}\text { Published online: } \\
\text { September 18, 2010 }\end{array}$ & $\begin{array}{l}\text { I 2010 S. Karger AG, Basel } \\
\text { ISSN 1662-0631 } \\
\text { www.karger.com/crg }\end{array}$ \\
\hline
\end{tabular}
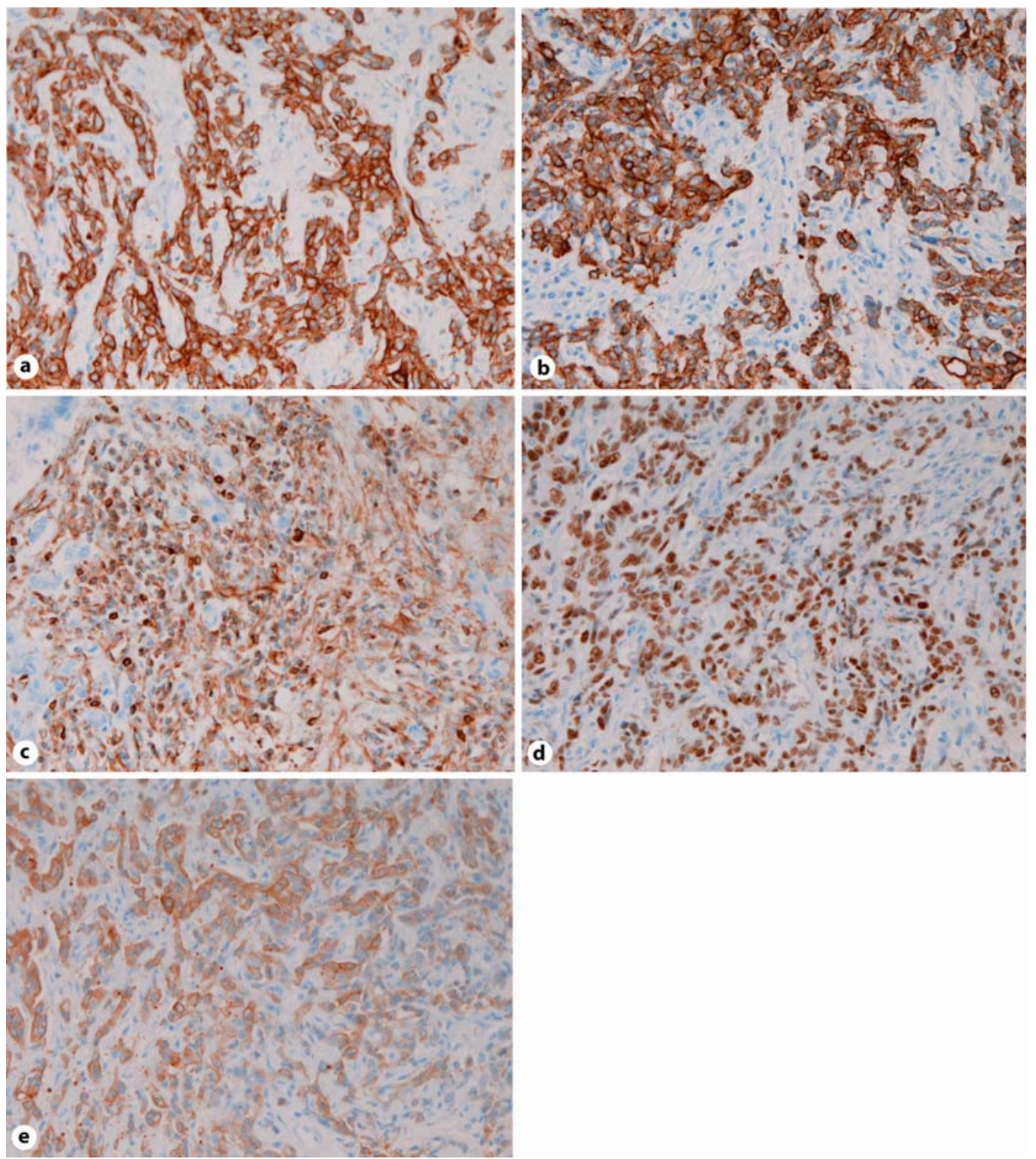

Fig. 3. a Positive reaction of CK7 in the spindle cell carcinoma element. Immunostaining, $\times 100$. b Positive reaction of CK18 in the spindle cell carcinoma element. Immunostaining, $\times 100$. c Positive reaction of vimentin in the spindle cell carcinoma element. Immunostaining, $\times 100$. d Positive reaction of p53 in the spindle cell carcinoma element. Immunostaining, $\times 100$. e Positive reaction of CEA in the spindle cell carcinoma element. Immunostaining, $\times 100$.

\section{References}

1 Nakajima T, Tajima Y, Sugano I, Nagao K, Kondo Y, Wada K: Intrahepatic cholangiocarcinoma with sarcomatous changes: clinicopathologic and immunohistochemical evaluation of seven cases. Cancer 1993;72:1872-1877.

2 Sasaki M, Nakanuma Y, Nagai Y, Nonomura A: Intrahepatic cholangiocarcinoma with sarcomatous transformation: an autopsy case. J Clin Gastroenterol 1991;13:220-225. 
3 Terada T, Notsumata K, Nakanuma Y: Biliary carcinosarcoma arising in nonparasitic simple cyst of the liver. Virchows Arch 1994;424:331-335.

-4 Shimada M, Takenaka K, Rikkimaru T, Hamatsu T, Yamashita Y, Kajiyama K, Taguchi K, Shirabe K, Sugimachi K: Characteristics of sarcomatous cholangiocarcinoma of the liver. Hepatogastroenterology 2000;47:956-961.

5 Shinoda M, Shimizu M, Mukai M, Tanabe M, Hashigichi N, Oda M, Kitajima M: Spindle cell carcinoma of the intrahepatic bile duct in a patient with primary sclerosing cholangitis. J Gastroenterol 2003;38:1091-1096.

6 Yoon GS, Choi DL: Sarcomatoid carcinoma of the common bile duct: a case report. Hepatogastroenterology 2004;51:106-109.

7 Albores Saavedra J, Gridler DJ, Wu J, Hensen DE, Goodman ZD: Giant cell tumor of the extrahepatic biliary tree: a clinicopathologic study of 4 cases and comparison with anaplastic spindle and giant cell carcinoma with osteoclast-like giant cells. Am J Surg Pathol 2006;30:495-500.

8 Oikawa H, Oka K, Nagakusa S, Fukunaga M, Sando N, Kashimura J, Hakozaki H: Spindle and giant cell type undifferentiated carcinoma arising in the common bile duct: a case report. Pathol Res Pract 2007;203:179-184.

-9 Nakanishi Y, Ito T, Kubota K, Takeda H, Yonemori A, Kawakami H, Zen Y, Kondo S: Spindle cell-type undifferentiated carcinoma of the common bile duct of the hepatic hilus: report of a case. Surg Today 2007;37:708-712.

10 Terada T, Kawaguchi M: Primary clear cell adenocarcinoma of the peritoneum. Tohoku J Exp Med 2005;206:271-275.

11 Terada T, Kawaguchi M, Furukawa K, Sekido Y, Osamura Y: Minute mixed ductal-endocrine carcinoma of the pancreas with predominant intraductal growth. Pathol Int 2002;52:740-746.

12 Terada T: Primary multiple extragastrointestinal stromal tumors of the omentum with different mutations of c-kit gene. World J Gastroenterol 2008;14:7256-7259.

13 Terada T: Gastrointestinal stromal tumor of the uterus: a case report with genetic analyses of c-kit and PDGFRA genes. Int J Gynecol Pathol 2009;28:29-33.

14 Terada T: Large endocervical polyp with cartilaginous and osseous metaplasia: a hitherto unreported entity. Int J Gynecol Pathol 2009;28:98-100. 